\title{
South American Economic Integration: Less Social Inequality?
}

\author{
Elizabeth Aponte Jaramillo \\ Autónoma de Occidente University, Cali, Colombia
}

\begin{abstract}
The South American countries, as with ones from the rest of the world have been immersed in the processes of globalization during the last two decades. An emerging question of this context is: How dynamic are these countries in terms of their foreign trade? Regarding this matter, the dates from Economic Commission for Latin America, CEPAL, about South American countries foreign trade show that in the late 1990s, exports increased to US135,000 millions of dollars, which practically doubled the value of the mid first decade of the 21st century; imports, on the other hand, also increased at a lower level, going from US131,000 million to US212,000 million of dollars in the same period. The behavior of the exports and imports has allowed a favorable commercial balance (US90,000 millions of dollars in 2005). Likewise, the variation of the Gross Domestic Product (GDP), increased until reaching to $5.8 \%$ in 2007 , before the international financial crisis ${ }^{1}$. There is also improvement in social terms; the poverty population proportion in Latin America was around 33.0\% in 2008, an indicator which decreased 10 percentage points in relation to 1999 (including the Central American countries). This paper shows the overview of foreign trade, economic growth and social inequality in South America during the last years. Given the Millennium Development Goals, set by the UNDP, this article seeks to contrast the commercial advancement of South American economies with the results in terms of social inequality. The analysis of key indicators shows that the dynamics of economic integration and foreign trade does not reflect on improving social equity and poverty reduction, therefore, the implementation of policies that target society to achieve this purpose are suggested.
\end{abstract}

Keywords: economic integration, quality of life, social equality, poverty

\section{Economic Growth and Social Inequality}

In recent literature about growth and income distribution, mainly protected by the World Bank and its adjacent institutes, not only the hypotheses prior to Simon Kuznets (1955) and Bhagwati (1991) are highlighted, authors, from whose ideas, stand that as economies grow and develop, better living conditions are experienced, until reaching a maximum level (according to the technological availability and commercial dynamics), but also that if globalization is considered as a powerful force which contributes to the positive growth of economies, and

Elizabeth Aponte Jaramillo, Ph.D. and Magister in Economics, Professor, Group of Research GIED, Autónoma de Occidente University.

Correspondence concerning this article should be addressed to Elizabeth Aponte Jaramillo, Calle 25\# 115-85 Km. 2 Vía Cali, Jamundí, Cali, Colombia. E-mail: eaponte@uao.edu.co.

1 The analysis is done from a structural perspective; therefore, the main data covers from before the international economic crisis of the current century. 
societies lower their levels of poverty, it is also true that in certain trade and commercial integration processes nations assume diverse risks. Therefore, due to this it is important to establish policies that minimize these risks and that maximize the opportunities for the poor population (Collier \& Dollar, 2002). Within this last context there are empirical studies (Dollar \& Kraay, 2001) whose support that is as long as the countries are immersed in processes of globalization, the following common world scenarios have come up mainly since the decade of the 1980s:

- Inequalities have not systematically intensified;

- Poverty has decreased;

- The gap between the rich and the poor has decreased.

It is clear that these ideas encompass society, yet each economy can experience these features with their own particularities, which bring them closer or move them away from the average, both positively as well as negatively.

\section{Foreign Trade and Social Inequality in CAN and MERCOSUR}

Table 1 synthesizes the total of foreign trade of the MERCOSUR and CAN economic blocks and their countries (1999, 2006), showing independently Chile and Venezuela, which at different times have had relation with the MERCOSUR and CAN, respectively.

Table 1

Foreign Trade and Relative Trade Balance

\begin{tabular}{|c|c|c|c|c|c|c|}
\hline & \multicolumn{2}{|c|}{$\begin{array}{l}\text { Export (millions of dollars FOB) } \\
(1)\end{array}$} & \multicolumn{2}{|c|}{$\begin{array}{l}\text { Import (millions of dollars FOB) } \\
(2)\end{array}$} & \multicolumn{2}{|c|}{$\begin{array}{l}\text { Relative trade balance } \\
{[(1)-(2)] /[(1)+(2)]}\end{array}$} \\
\hline & 1999 & 2006 & 1999 & 2006 & 1999 & 2006 \\
\hline \multicolumn{7}{|c|}{ MERCOSUR } \\
\hline Argentina & 23,332 & 46,546 & 25,508 & 34,154 & -0.04 & 0.15 \\
\hline Brazil & 48,011 & 137,806 & 51,747 & 91,343 & -0.04 & 0.20 \\
\hline Paraguay & 741 & 1,843 & 1,906 & 4,758 & -0.44 & -0.44 \\
\hline Uruguay & 2,237 & 3,952 & 3,356 & 4,775 & -0.20 & -0.09 \\
\hline Total & 73,321 & 190,147 & 82,517 & 135,030 & -0.05 & 0.17 \\
\hline Chile & 15,619 & 58,679 & 13,891 & 38,406 & 0.06 & 0.21 \\
\hline \multicolumn{7}{|l|}{ CAN } \\
\hline Bolivia & 1,402 & 4,223 & 1,835 & 2,825 & -0.13 & 0.20 \\
\hline Colombia & 11,617 & 24,391 & 10,659 & 26,162 & 0.04 & -0.04 \\
\hline Ecuador & 4,451 & 12,728 & 3,017 & 12,114 & 0.19 & 0.02 \\
\hline Peru & 5,932 & 23,765 & 6,823 & 15,312 & -0.07 & 0.22 \\
\hline Total & 23,402 & 65,107 & 22,334 & 56,413 & 0.02 & 0.07 \\
\hline Venezuela & 20,076 & 61,385 & 13,554 & 30,559 & 0.19 & 0.34 \\
\hline
\end{tabular}

Note. Source: Authors' calculations based on CEPAL statistics, CEPALSTAT http:// www.eclac.org.

In particular, the total of foreign trade of the MERCOSUR increased 128\% in values (1999-2006), Brazil being the country with the highest participation $(70 \%)$ in this trade, however, it is pointed out that this country lost four percentage points of weight on this total; meanwhile Paraguay shows a noticeable recovery. For its part, the CAN had a high rate of growth (288\%) in the same period, although its amount of trade is under the total generated in MERCOSUR, being Colombia the nation with the highest relative weight, and as happened to 
Paraguay, in this group Ecuador is an outstanding country.

From Table 1, it is important to point out that the indicator of the relative trade balance shows, in general, a result of balanced foreign trade (same amount of exports as imports) ${ }^{2}$. But, according to Table 2, the participation of trade intra-regions is low, principally to countries of the CAN, suggesting insufficient use of the agreements and an unbalanced exchange in terms of trading intra-industries (South-South trade) ${ }^{3}$.

Table 2

Intra-region Trade of Goods in 2006 (Millions of Dollars FOB)

\begin{tabular}{lccc}
\hline & Block total trade (1) & World total trade (2) & Relation (1)/(2) \\
\hline MERCOSUR & & & 28.1 \\
Argentina & 22,669 & 80,700 & 10.1 \\
Brazil & 23,032 & 229,149 & 35.8 \\
Uruguay & 3,124 & 8,727 & 40.7 \\
Paraguay & 2,683 & 6,601 & 13.19 \\
Chile & 12,808 & 97,085 & 16.1 \\
\hline CAN & & & 13.3 \\
Colombia & 8,142 & 50,553 & 17.8 \\
Bolivia & 936 & 7,048 & 10.6 \\
Ecuador & 4,412 & 24,841 & 4.41 \\
Peru & 4,142 & 39,076 & 91,944 \\
Venezuela & 4,053 & 964 &
\end{tabular}

Note. Source: Authors’ calculations based on CEPAL statistics, CEPALSTAT http://www.eclac.org.

In the social context, Table 3 suggests impacts of this fact and shows how some economies have substantial improvements, such as Ecuador. A high unemployment rate, added to inequitable processes of income redistribution result in poor results in the GDP per capita, although the total GDP presents important growth (see Table 4). Far from reaching the levels of the developed countries, CAN countries joint with Uruguay of the MERCOSUR, stand out for having the fewest products per capita in the region. Brazil and Chile, in turn considered as leading structures in the economic field in Latin America, do not precisely have an outstanding indicator. At the same time, Argentina seems to have left behind its crisis from the early 21st century and Uruguay, in turn, keeps on being an organized society.

Table 3

Unemployment Rate

\begin{tabular}{lrc}
\hline & 1999 & 2006 \\
\hline MERCOSUR & & \\
\hline Argentina & 14.3 & 10.2 \\
Brazil & 7.6 & 10.0 \\
Paraguay & 9.4 & 8.9 \\
Uruguay & 11.3 & 11.4 \\
Total & $10.7^{*}$ & $10.1^{*}$ \\
Chile & 9.8 & 7.8 \\
\hline
\end{tabular}

${ }^{2}$ Indicator Relative Trade Balance (RTB) allows know the tendency (exports and imports) in the foreign trade of a country. If: $-1 \leq \mathrm{RTB} \leq-0.33$ : net importer; $-0.33<\mathrm{RTB} \leq 0.33$ : there is equilibrium; $0.33<\mathrm{RTB} \leq 1$ : net exporter.

3 The theory of trading intra-industries has been studying for Balassa (1986) and Krugman (1988). 
(Table 3 continued)

\begin{tabular}{lcc}
\hline & 1999 & 2006 \\
\hline CAN & & \\
\hline Bolivia & 6.1 & 8.0 \\
Colombia & 19.4 & 13.1 \\
Ecuador & 15.1 & 8.1 \\
Peru & 9.4 & 8.5 \\
Total & $12.5^{*}$ & $9.4^{*}$ \\
Venezuela & 15.0 & 9.9 \\
\hline
\end{tabular}

Note. ${ }^{*}$ Average unemployment rate of trade block; Source: Authors' calculations based on CEPAL statistics, CEPALSTAT http://www.eclac.org.

Table 4

Gross Domestic Product Per Capita (Constant Dollars of 2000)

\begin{tabular}{lcc}
\hline & 1999 & 2006 \\
\hline MERCOSUR & & \\
\hline Argentina & 7,852 & 8,696 \\
Brazil & 3,600 & 4,087 \\
Paraguay & 1,401 & 1,397 \\
Uruguay & 6,396 & 7,006 \\
Chile & 4,747 & 5,892 \\
\hline CAN & & \\
\hline Bolivia & 1,006 & 1,096 \\
Colombia & 2,337 & 2,789 \\
Ecuador & 1,277 & 1,632 \\
Peru & 2,024 & 2,504 \\
Venezuela & 4,720 & 5,370 \\
\hline
\end{tabular}

Note. Source: Authors' calculations based on CEPAL statistics, CEPALSTAT http://www.eclac.org.

In more social terms and mainly of income distribution, in these economies the Gini index keeps on showing a medium behavior of distribution of product (see Table 5). All the countries are far away from an equitable trend, mainly the two economies that have been outstanding for presenting the highest trade amount among their groups, meaning, Brazil and Colombia. Comparing this result with the Human Development Index (see Table 6), it is concluded that in MERCOSUR the conditions of social development are better than in CAN. Nevertheless, it is not precisely Brazil, with its economic development, which best supports this environment, Argentina and Uruguay stand out here.

Table 5

Gini Index

\begin{tabular}{lll}
\hline & Last years of 1990s & First years of century 21 \\
\hline MERCOSUR & & \\
\hline Argentina & 0.539 & 0.519 \\
Brazil & 0.639 & 0.594 \\
Paraguay & 0.570 & 0.527 \\
Uruguay & $0.440^{*}$ & 0.445 \\
Chile & 0.564 & 0.522 \\
\hline
\end{tabular}


(Table 5 continued)

\begin{tabular}{|c|c|c|c|c|}
\hline & & Last years of 1990s & First years of century 21 & \\
\hline \multicolumn{5}{|l|}{ CAN } \\
\hline Bolivia & & 0.586 & 0.565 & \\
\hline Colombia & & 0.572 & 0.584 & \\
\hline Ecuador & & $0.526^{*}$ & 0.504 & \\
\hline Peru & & 0.525 & 0.576 & \\
\hline Venezuela & & 0.500 & 0.490 & \\
\hline \multirow{2}{*}{\multicolumn{5}{|c|}{$\begin{array}{l}\text { Note. }{ }^{*} \text { Corresponds to the urban area. } \\
\text { http://www.eclac.org. } \\
\text { Table } 6\end{array}$}} \\
\hline & & & & \\
\hline \multicolumn{5}{|c|}{ Human Development Index (HDI) 2006} \\
\hline & HDI & & HDI & \\
\hline MERCOSUR & & CAN & & \\
\hline Argentina & 0.861 & Bolivia & 0.726 & \\
\hline Brazil & 0.08 & Colombia & 0.800 & \\
\hline Paraguay & 0.757 & Ecuador & 0.805 & \\
\hline Uruguay & 0.860 & Peru & 0.799 & \\
\hline Chile & 0.874 & Venezuela & 0.833 & \\
\hline
\end{tabular}

Note. Source: United Nations, PNUD, 2009.

It is interesting to observe how the population level generates important contrasts with the urbanization of cities and the states of poverty (see Tables 7 and 8). In general, MERCOSUR, despite having the higher mass of population, presents better indicators than CAN. This result seems to be obvious, if it is understood that in MERCOSUR there are higher processes of industrialization and modernization than that in CAN. Nevertheless, it's noticeable that the levels of poverty have tended to decrease in the region; the exceptional cases are Paraguay and Uruguay in MERCOSUR, and Colombia and Bolivia in CAN.

Table 7

Population 2005 (Thousands of People)

\begin{tabular}{|c|c|c|c|c|}
\hline & Total (1) & Urban (2) & Relation \% (2)/(1) & Poor population \\
\hline \multicolumn{5}{|c|}{ MERCOSUR } \\
\hline Argentina & 38,592 & 35,428 & 91.8 & 7,440 \\
\hline Brazil & 187,601 & 156,450 & 83.4 & 46,935 \\
\hline Paraguay & 5,899 & 3,451 & 58.5 & 1,898 \\
\hline Uruguay & 3,317 & 3,050 & 92.0 & 610 \\
\hline Total & 235,409 & 198,379 & 84.3 & \\
\hline Chile & 16,267 & 14,080 & 86.6 & 1,408 \\
\hline \multicolumn{5}{|l|}{ CAN } \\
\hline Bolivia & 9,427 & 6,055 & 64.2 & 3,270 \\
\hline Colombia & 44,907 & 34,409 & 76.6 & 15,484 \\
\hline Ecuador & 13,211 & 8,299 & 62.8 & 3,320 \\
\hline Peru & 27,254 & 19,804 & 72.7 & 6,139 \\
\hline Total & 94,799 & 68,567 & 72.3 & \\
\hline Venezuela & 26,556 & 24,636 & 92.8 & 5,174 \\
\hline
\end{tabular}

Note. Source: Authors' calculations based on CEPAL statistics, CEPALSTAT http://www.eclac.org. 
Table 8

Urban Poverty and Urban Poverty Severity (Total Population Percentage)

\begin{tabular}{|c|c|c|c|c|}
\hline & \multicolumn{2}{|c|}{ Urban poverty } & \multicolumn{2}{|c|}{ Urban poverty severety } \\
\hline & Last years of 1990s & First years of century 21 & Last years of 1990s & First years of century 21 \\
\hline \multicolumn{5}{|c|}{ MERCOSUR } \\
\hline Argentina & 23.7 & 21.0 & 6.70 & 7.20 \\
\hline Brazil & 32.9 & 29.9 & 9.30 & 6.70 \\
\hline Paraguay & 49.0 & 55.0 & 73.9 & 23.20 \\
\hline Uruguay & 9.4 & 19.7 & 1.8 & 4.10 \\
\hline Chile & 20.7 & 10.40 & 5.10 & 3.20 \\
\hline \multicolumn{5}{|l|}{ CAN } \\
\hline Bolivia & 48.7 & 53.80 & 19.8 & 20.2 \\
\hline Colombia & 43.1 & 45.40 & 21.9 & 18.2 \\
\hline Ecuador & 63.5 & 39.90 & 31.3 & 12.8 \\
\hline Peru & 36.1 & 31.20 & 9.30 & 4.9 \\
\hline Venezuela & $49.4^{*}$ & $30.2^{*}$ & $21.7^{* *}$ & $9.9^{* *}$ \\
\hline
\end{tabular}

Regarding the urban population and poverty relationship, it can be deduced that whereas more rural population the countries have, more high level of poverty there is. Brazil and Colombia, the biggest countries in their blocks, with high indexes of rural population, present high poverty indexes $30 \%$ and $45 \%$ respectively. Argentina and Uruguay, with a low index of rural population presents a low poverty index $21 \%$ and $20 \%$, and both, the lowest indexes in both blocks.

Independent of the contrasts that can be established among the countries of these economic blocks, an outstanding issue is that none of these nations has a high medium income position in the world economy, a range that is considered swing between US $\$ 10,000-U S \$ 11,000$. Doubtless, this feature results in economic concentrations that are insufficient to reach potential market limits and, through this process to have a positive development of agglomeration economies (World Bank, 2009).

From the previous information, it can be deduced that the existing agglomerations in the biggest countries in South America, like in the case of Brazil (acknowledgment the importance of some of its main cities), are not necessarily related to strong economies of urbanization. Part of the explanation of this situation at a national level may be found in the external des-economies generated by the disorganized growth of some cities and the lack of an ample diversification of markets and products (Corporación Andina de Fomento, 2010). That is why the benefits of economic development do not translate into social development.

\section{Conclusions}

The economic and social analysis presented to the two economic blocks of South America reflects that the dynamic of foreign trade in CAN and MERCOSUR has not been able to close the poverty gap.

In this context, it is clear that these countries are not taking full advantage of the synergies that may arise under the schemes should be free trade and economic integration. Moreover, they do not provide sufficient complementary social policies to help close the social gaps.

Despite the countries of the region have worked together on the Millennium Development Goals, poverty is 
still high in some countries of South America and in others is still increasing. Therefore, with high unemployment rates and a quite inequitable indicator of distribution, although the human development indexes are medium level, it is hard to prevent these countries from falling into poverty.

Nevertheless, there is no doubt that as countries widen the frame of action in the international markets and, they can achieve true technologic exchange relationships, and the economic agglomeration environment may ostensibly improve their economic and social conditions. According to the reported information, a country which seems to be in the vanguard is Argentina, contrasting substantially with the results of the CAN, countries that have obtained minimal progress economically and socially.

But also, in generally, these countries are not working on both fronts in the same time (economic and social), they forget the integrate actions of macroeconomics and therefore is sensed a hypothesis: There is not social integration. So there are not economies of agglomeration.

However, internationally, the different agencies and supranational governments continue betting on international trade as an engine for development and poverty reduction, for example, World Bank, World Trade Organization and Inter-American Development Bank.

In conclusion, although the trade growth and trade integration create opportunities to improve income levels of countries, the use of these opportunities appears conditioned to the implementation of complementary policies regarding the improvement of income distribution.

\section{References}

Balassa, B. (1986). Intraindustry specialization. European Economic Review, 30. North Holland.

Banco, M. (2009). Informe Anual del Banco Mundial-Resumen Ejecutivo. Washington, D.C..

Bhagwati, J. (1991). Political economy and international economics (D. Irwin, Ed.). Cambridge: MIT Press.

CEPAL. (2009). Anuario Estadístico de América Latina y el Caribe. Santiago de Chile.

Collier, P., \& Dollar, D. (2002). Globalization, growth and poverty: Building and inclusive world. World Bank, Bussiness \& Economics.

Corporación Andina De Fomento. (2010). Desarrollo local: Hacia un nuevo protagonismo de las ciudades y regiones, Reporte de Economía y Desarrollo. Caracas.

Dollar, D., \& Kraay, A. (2001). Comercio exterior, crecimiento y pobreza. Revista Finanzas y Desarrollo, 33(3), 16-19.

Krugman, P. (1988). La nueva teoría del comercio internacional y los países menos desarrollados. El Trimestre Económico, LV(1), 41-66.

Kuznets, S. (1955). Economic growth and income inequality. American Economic Review, 45, 1-28.

Naciones Unidas. (2009). Programa para el Desarrollo PNUD, Informe Sobre Desarrollo Humano. Washington, D.C.. 